\title{
Pengendalian Pencemaran Limbah Domestik sebagai Upaya Rehabilitasi Pesisir di Desa Malangrapat, Kabupaten Bintan
}

\author{
Ginanjar Pratama ${ }^{1}$, Itok Dwi Kurniawan ${ }^{2 *}$, dan Aidil Fadli Ilhamdy ${ }^{3}$ \\ ${ }^{1}$ Jurusan Perikanan, Fakultas Pertanian, Universitas Sultan Ageng Tirtayasa \\ ${ }^{2}$ Prodi Ilmu Hukum, Fakultas Hukum, Universitas Sebelas Maret \\ ${ }^{3}$ Jurusan Teknologi Hasil Perikanan, Fakultas Ilmu Kelautan dan Perikanan, Universitas Maritim \\ Raja Ali Haji \\ *Corresponding Author: itokdwikurniawan@staff.uns.ac.id
}

\begin{abstract}
ABSTRAK
Desa Malangrapat merupakan salah satu destinasi wisata pantai yang sangat menjanjikan di wilayah Kabupaten Bintan. Banyaknya wisatawan yang datang tiap tahun membuat daerah tersebut mengalami penurunan kualitas lingkungan pantai akibat buangan sampah domestik. Hal itu terlihat dari banyaknya sampah yang berada di bibir pantai dan berkurangnya tangkapan nelayan. Upaya awal dalam menjaga kelestarian lingkungan pesisir yaitu dengan cara sosialisasi tentang pengendalian limbah domestik di daerah tersebut. Peran serta masyarakat untuk menjaga daerah wisata di Desa Malangrapat sangat berpengaruh, mengingat sebagian besar masyarakat berprofesi sebagai nelayan. Tujuan kegiatan ini adalah mengedukasi masyarakat nelayan agar mengetahui cara mengendalikan cemaran limbah domestik. Tahapan kegiatan ini yaitu, tahap persiapan (koordinasi dengan Kepala Desa), field study (survei limbah domestik di pesisir pantai dan survei pengetahuan masyarakat tentang limbah domestik), dan yang terakhir adalah sosialisasi-evaluasi (sosialisasi tentang pengendalian pencemaran limbah domestik dan evaluasi pengujian baku mutu air). Hasil yang diperoleh dari kegiatan ini adalah meningkatnya pemahaman masyarakat tentang cara mengendalikan cemaran limbah domestik.
\end{abstract}

Kata kunci: limbah domestik, nelayan, pencemaran, pesisir, wisata pantai

\begin{abstract}
Malangrapat Village is one of the tourism destinations in the Bintan Regency area. The tourists who come every year makes the area experience a decrease in the quality of the environment due to domestic waste disposal. This can be seen from the amount of waste, and the reduction in fishing catches. The initial effort in preserving the coastal environment was the socialization of domestic waste control in the area. The role of the community to protect the tourism area in Malangrapat Village was very influential, considering that most of the people work as fishermen. The objective of this study was to educate the fishing community so that they know how to control the pollution of domestic waste. The stages of this study were the preparatory (coordination with the Head Village), a field study (a survey of domestic waste on the coast and survey of community knowledge about domestic waste), and the last was socialization-evaluation (the socialization about controlling domestic waste pollution and evaluation of water quality test). The results obtained from this study are increased public understanding of how to control domestic waste pollution in the area.
\end{abstract}

Keywords: beach tourism, coast, fishermen, domestic waste, pollution

\section{PENDAHULUAN}

Perkembangan aktifitas manusia yang terjadi di sekitar wilayah pesisir akan memberikan dampak adanya pencemaran perairan. Ekosistem perairan merupakan bagian integral dari lingkungan hidup manusia yang relatif banyak dipengaruhi oleh berbagai macam kegiatan manusia serta dapat dijadikan sebagai pedoman untuk kerusakan lingkungan (Muchtar, 2012). Salah satu dampaknya adalah aktivitas sosial-ekonomi yang menurun di wilayah pesisir 
(Suriadarma, 2011). Pencemaran lingkungan menyebabkan kualitas lingkungan menjadi menurun sehingga akan berdampak pada sektor wisata dan penangkapan di wilayah pesisir. Pencemaran bahan organik berdasarkan sumbernya dapat dibedakan menjadi tiga, yaitu limbah domestik, limbah industri dan limbah pertanian (Tchobanoglous et al., 2003).

Limbah domestik umumnya mengandung lima sifat utama yaitu mengandung bakteri, parasit dan kemungkinan virus, dalam jumlah banyak sering mengkontaminasi dalam tubuh kerang-kerangan dan areal mandi di pesisir laut, mengandung bahan organik dan padatan tersuspensi sehingga BOD5 tinggi, padatan organik akan terurai secara biologis, sehingga akibatnya kandungan oksigen berkurang, kandungan unsur hara terutama fosfor dan nitrogen tinggi sehingga menyebabkan terjadi eutrofikasi, mengandung bahan terapung berupa bahan-bahan organik dan anorganik dalam bentuk tersuspensi (Sawyer et al., 1994). Limbah domestik yang paling dominan adalah jenis organik yang berupa kotoran manusia dan hewan. Jenis limbah domestik yang lain adalah limbah domestik anorganik yang diakibatkan oleh plastik serta penggunaan deterjen, sampo, cairan pemutih, pewangi dan bahan kimia lainnya (Yudo, 2010). Limbah domestik jenis ini relatif lebih sulit untuk dihancurkan. Jika kuantitas dan intensitas limbah domestik ini masih dalam batas normal, alam masih mampu melakukan proses kimia, fisika, dan biologi secara alami (Laapo et al., 2009). Namun, peningkatan populasi manusia telah menyebabkan peningkatan kuantitas dan intensitas pembuangan limbah domestik sehingga membuat proses penguraian limbah secara alami menjadi tidak seimbang (Hindriani et al., 2013). Selain itu, limbah domestik jenis plastik sangat berpengaruh terhadap kesehatan manusia karena dapat mengakibatkan timbulnya penyakit kanker dan kerusakan jaringan pada tubuh manusia (karsinogenik) (Karuniastuti, 2013).

Aktivitas wilayah pesisir di Kabupaten Bintan setiap tahunnya mengalami peningkatan, hal itu dapat dilihat dari banyaknya hotel, rumah makan dan perumahan penduduk yang dibangun. Jumlah hotel dan rumah makan di Kabupaten Bintan pada tahun 2014 naik dari 10 menjadi 35 hotel dan untuk rumah makan dari 350 menjadi 550 selama 5 tahun terakhir (BPS, 2015). Pencemaran yang terjadi akibat limbah domestik sejatinya merupakan ancaman nyata yang dapat merusak ekosistem pesisir. Pencemaran laut akibat wisata sebenarnya relatif lebih kecil dibandingkan dengan limbah domestik (Laapo et al., 2009). Elyazar et al. (2007) menyatakan bahwa aktivitas hotel dan restoran, pemukiman dan nelayan berpotensi menghasilkan limbah terbesar yang bersumber dari aktivitas rumah tangga.

Terkait dengan permasalahan tersebut maka diperlukan solusi untuk mengatasinya. Salah satu solusi yang dapat diberikan untuk pengendalian limbah domestik adalah mengedukasi tentang bahaya dan dampak yang ditimbulkan dari pencemaran kepada masyarakat. Adapun sasaran edukasinya adalah di Desa Malangrapat, Kabupaten Bintan. Desa Malangrapat merupakan salah satu destinasi wisata di Pulau Bintan karena memiliki banyak pantai yang indah. Keindahan pantai di Desa Malangrapat semakin hari semakin tergerus oleh banyaknya aktivitas wisata dan rumah tangga akibat adanya limbah domestik. Hal ini yang menjadi fokus utama dalam kegiatan pengabdian ini untuk mengedukasi masyarakat yang sebagian besar adalah nelayan. Adapun tujuan kegiatan ini adalah mengedukasi masyarakat nelayan agar mengetahui cara mengendalikan cemaran limbah domestik.

\section{METODE}

Kegiatan pengabdian ini dilakukan dengan tiga tahapan metode yaitu tahap persiapan, field study (survei) dan sosialisasievaluasi (Rijati et al., 2012).

1. Tahap persiapan dilakukan dengan cara berkoordinasi dengan Kepala Desa Malangrapat Kabupaten Bintan. Tahap ini dilakukan untuk merencanakan kegiatan yang akan dilakukan bersama dengan mitra yang dituju. Rencana ini kemudian disusun sesuai dengan kesepakatan bersama dengan mitra kegiatan.

2. Tahap field study (survei) di bagi menjadi dua yaitu tentang limbah domestik di pesisir pantai dan tentang pengetahuan masyarakat terhadap limbah domestik di pesisir. Pada tahap pertama dilakukan survei keadaan limbah domestik di pesisir Desa Malangrapat. Pada tahap kedua dilakukan survei pengetahuan masyarakat tentang sumber bahan pencemar, cara pengelolaan limbah, dan dampak pencemaran terhadap perairan kepada 30 orang responden yang mewakili Desa Malangrapat. Tahap ini 
dilakukan untuk mengumpulkan data tentang pengetahuan responden tentang bahaya limbah domestik terhadap perairan.

3. Pada tahap sosialisasi-evaluasi diperkenalkan tentang sumber bahan pencemar, cara pengelolaan limbah, dan dampak pencemaran terhadap perairan. Pelaksanaan sosialisasi ini diberikan kepada 30 orang responden yang telah melalui tahap survei pengetahuan sebagai perwakilan masyarakat dari Desa Malangrapat. Pada tahap evaluasi akhir diberikan petunjuk tentang pengujian baku mutu perairan dengan sampel air menggunakan test-kit sehingga dapat diketahui perbedaan mendasar tentang kandungan kimia di suatu perairan.

\section{HASIL DAN PEMBAHASAN}

Kegiatan pengabdian masyarakat diawali dengan menemui Kepala Desa Malangrapat sebagai pelaksanaan koordinasi awal (Gambar 1). Kegiatan tersebut dilakukan dengan cara memberikan gambaran tentang kegiatan yang akan dilakukan oleh tim peneliti. Selanjutnya dipaparkan tahapan-tahapan yang dilakukan dalam kegiatan pengabdian ini.

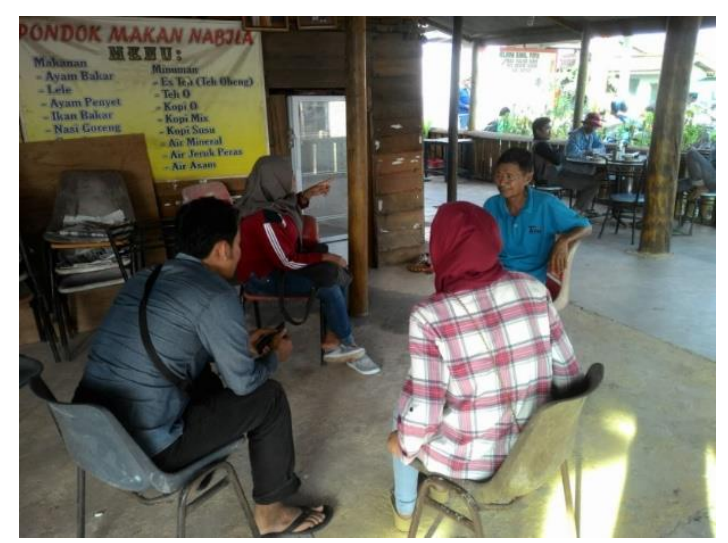

Gambar 1. Koordinasi dengan Kepala Desa Malangrapat

Hasil dari koordinasi awal didapatkan bahwa untuk pelaksanaan survei limbah domestik akan didampingi oleh perwakilan dari desa, sedangkan untuk survei pengetahuan masyarakat dan sosialisasi-evaluasi dilaksanakan di Balai Desa Malangrapat.

Pada tahap kedua dilakukan survei ke daerah pesisir Desa Malangrapat, salah satu pantai yang dikunjungi adalah Pantai Trikora (Gambar 2) yang merupakan destinasi andalan di wilayah tersebut. Berdasarkan hasil survei ditemukan beberapa limbah domestik berupa styrofoam dan plastik bekas deterjen (Gambar 3 dan 4). Limbah tersebut sangat berbahaya mengingat akan berdampak pada kelestarian sumberdaya dari biota perairan. Limbah plastik jika masuk ke dalam perairan semakin lama akan semakin terkikis dan akhirnya menjadi mikroplastik. Mikroplastik diketahui sangat berbahaya bagi organisme akuatik karena bersifat toksik sehingga dapat menghambat laju pertumbuhan dan menyebabkan kematian jika masuk ke dalam sel (Jovanovic, 2017). Selain limbah plastik, limbah lain berupa deterjen dan bahan kimia dari rumah tangga akan menyebabkan kondisi kimia perairan akan menjadi terganggu jika terus menerus masuk ke dalam perairan (Laapo et al., 2009). Salah satu contohnya adalah blooming algae yang menyebabkan organisme lain tidak mendapatkan ruang hidup sehingga menyebabkan kematian massal (Elyazar et al., 2007).

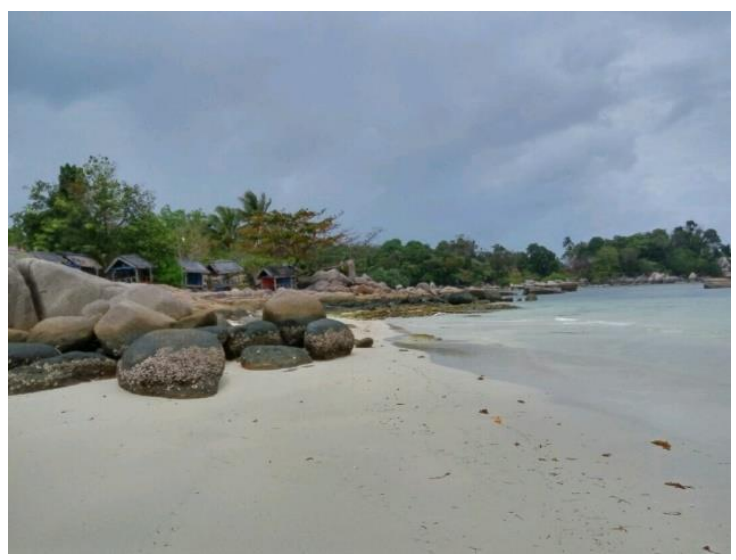

Gambar 2. Pantai Trikora di Desa Malangrapat

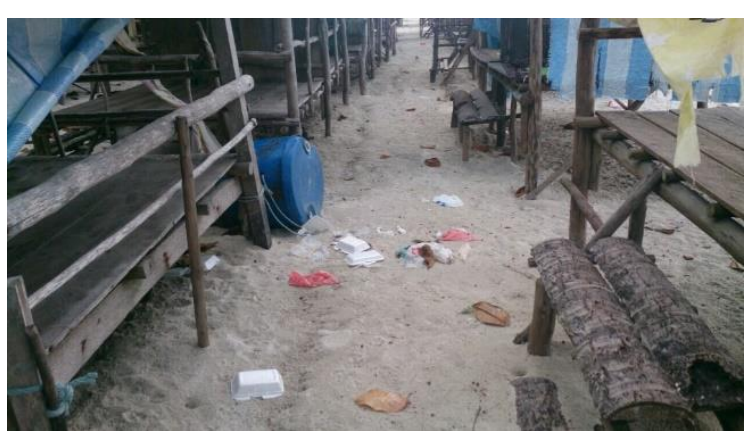

Gambar 3. Limbah domestik masyarakat

Tahap selanjutnya dari kegiatan ini adalah survei pengetahuan dan sosialisasi pengendalian pencemaran limbah domestik (Gambar 5). Kegiatan ini dilakukan di Balai Desa Malangrapat, dengan tahapan survei awal kepada perwakilan masyarakat sebanyak 30 orang. 


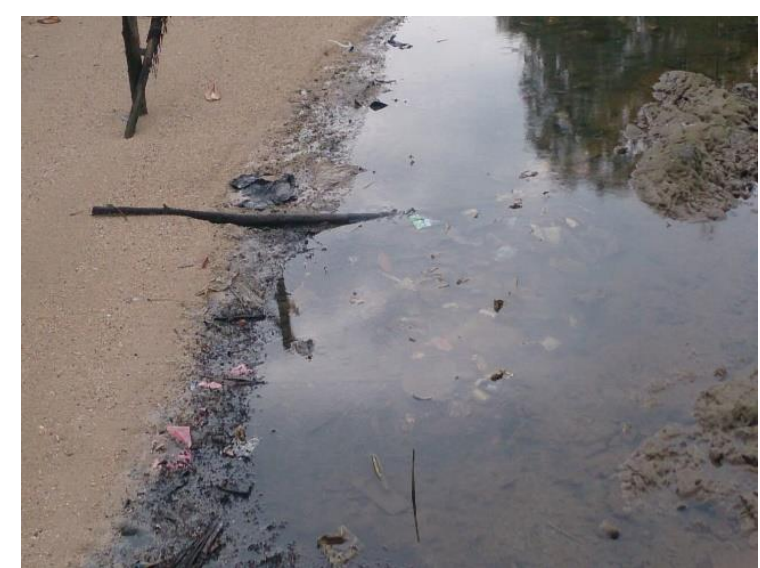

Gambar 4. Limbah domestik yang berada di perairan
Pada survei ini diberikan beberapa pertanyaan mengenai limbah domestik yang meliputi jenis pencemaran, sumber pencemaran, bahaya pencemaran, penyakit akibat pencemaran dan cara pengelolaan sampah. Hasil survei didapatkan untuk pertanyaan tentang penyakit akibat pencemaran sebanyak 25 responden menjawab mengetahui sedangkan sisanya kurang paham, sedangkan untuk pertanyaan cara mengelola sampah 27 responden menjawab mengetahui dan sisanya kurang paham. Hasil ini mengindikasikan bahwa sebagian besar masyarakat mengetahui tentang bahaya yang ditimbulkan dari limbah domestik (Tabel 1).

Tabel 1. Survei pengetahuan pencemaran limbah domestik

\begin{tabular}{|c|c|c|c|}
\hline No. & Pertanyaan & Mengetahui & Kurang Paham \\
\hline 1. & $\begin{array}{l}\text { Apakah Bapak/Ibu mengetahui tentang jenis-jenis } \\
\text { cemaran? }\end{array}$ & 30 & - \\
\hline 2. & $\begin{array}{l}\text { Apakah Bapak/Ibu mengetahui tentang sumber-sumber } \\
\text { cemaran? }\end{array}$ & 30 & - \\
\hline 3. & $\begin{array}{l}\text { Apakah Bapak/Ibu mengetahui tentang bahaya akibat } \\
\text { pencemaran pada lingkungan perairan? }\end{array}$ & 30 & - \\
\hline 4. & $\begin{array}{l}\text { Apakah Bapak/Ibu mengetahui tentang penyakit akibat } \\
\text { pencemaran? }\end{array}$ & 25 & 5 \\
\hline 5. & Apakah Bapak/Ibu mengetahui cara mengelola sampah? & 27 & 3 \\
\hline
\end{tabular}

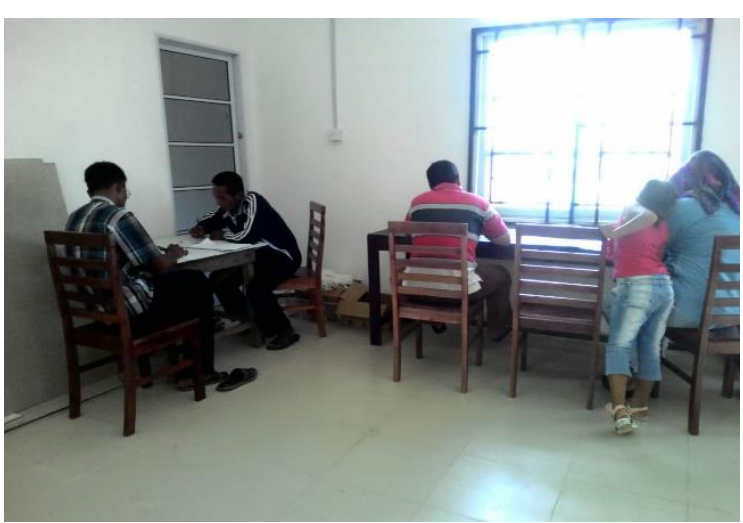

Gambar 5. Survei pengetahuan masyarakat tentang limbah domestik

Kegiatan sosialisasi dilakukan setelah tahapan survei, kegiatan ini dilakukan dengan metode pembelajaran tanya jawab (Gambar 6). Adapun poin-poin utama dalam sosialisasi ini adalah tentang jenis-jenis pencemar (cemaran air, tanah, udara) dan sumber-sumber pencemar (kimia organik, kimia anorganik biologis dan fisik) yang diakibatkan oleh limbah domestik. Selanjutnya adalah tentang bahaya pencemaran terhadap lingkungan perairan (coral bleaching, blooming alga, mikroplastik, kematian massal biota) dan kesehatan manusia (keracunan, pertumbuhan lambat, inflammatory dan sebagainya). Poin terakhir adalah tentang cara mengelola limbah domestik yaitu pengenalan terhadap teknologi 3R (reuse, reduce, recycle) sehingga diharapkan dapat dikembangkan menjadi produk yang memiliki nilai jual. Selanjutnya dilakukan test-kit peraga untuk mengetahui kualitas suatu perairan sesuai aturan baku mutu perairan dengan cara membandingkan sampel air minum, sampel air laut di sekitar dan sampel air yang diberi deterjen (Gambar 7).

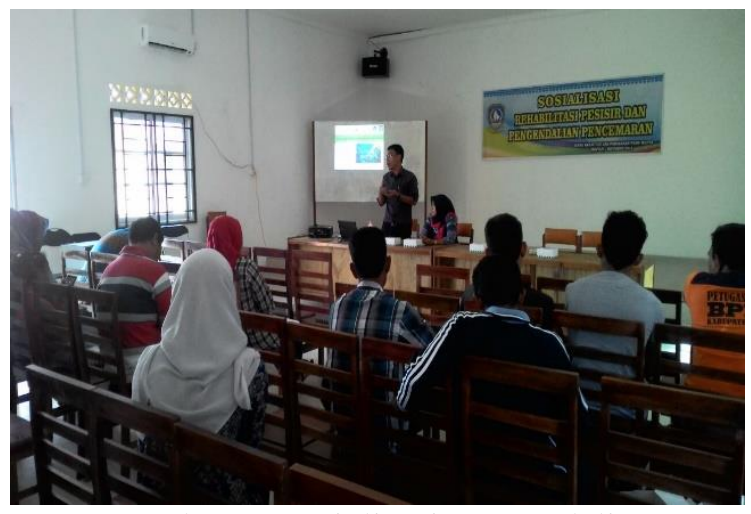

Gambar 6. Sosialisasi pengendalian pencemaran limbah domestik 


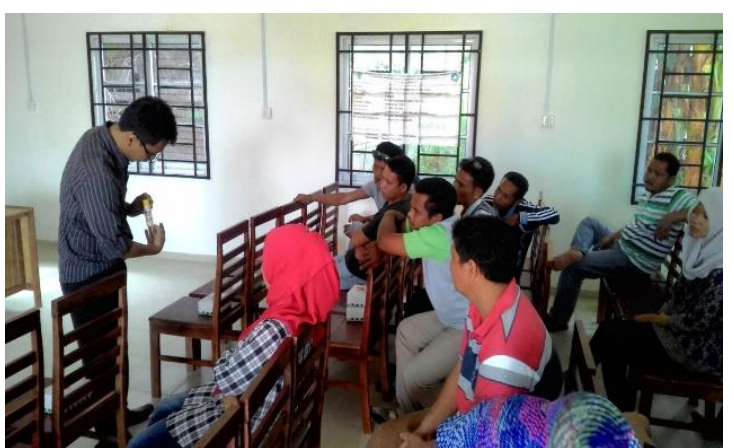

Gambar 7. Penjelasan uji test-kit kualitas air

Alat peraga ini dapat mengukur kandungan $\mathrm{pH}$, nitrat, nitrit dan sulfat dalam suatu perairan. Hasilnya didapatkan untuk sampel air minum dan sampel air laut masih dalam aturan baku mutu suatu perairan, sedangkan untuk sampel air yang diberi deterjen hasilnya berada diambang batas baku mutu perairan. Kegiatan ini dapat mengedukasi secara langsung masyarakat. Hal itu terlihat dari hasil evaluasi pengetahuan warga setelah mengetahui cara mengendalikan limbah domestik yang berada di perairan (Tabel 2).

Tabel 2. Hasil Evaluasi Pengetahuan Pencemaran Limbah Domestik setelah Sosialisasi

\begin{tabular}{llcc}
\hline No. & Pertanyaan & Mengetahui & Kurang Paham \\
\hline 1. & $\begin{array}{l}\text { Apakah Bapak/Ibu mengetahui tentang jenis-jenis } \\
\text { cemaran? }\end{array}$ & 30 & - \\
\hline 2. & $\begin{array}{l}\text { Apakah Bapak/Ibu mengetahui tentang sumber-sumber } \\
\text { cemaran? }\end{array}$ & 30 & - \\
\hline 3. & $\begin{array}{l}\text { Apakah Bapak/Ibu mengetahui tentang bahaya akibat } \\
\text { pencemaran pada lingkungan perairan? }\end{array}$ & 30 & - \\
\hline 4. & $\begin{array}{l}\text { Apakah Bapak/Ibu mengetahui tentang penyakit akibat } \\
\text { pencemaran? }\end{array}$ & 30 & - \\
\hline 5. & Apakah Bapak/Ibu mengetahui cara mengelola sampah? & 30 & - \\
\hline
\end{tabular}

\section{KESIMPULAN}

Kegiatan pengabdian ini telah dilaksanakan kepada masyarakat dan diperoleh kesimpulan bahwa secara umum peserta sosialisasi sebanyak 30 warga yang mewakili Desa Malangrapat mendapatkan wawasan dan pengetahuan mengenai pengelolaan limbah domestik. Hal ini terlihat dari meningkatnya pemahaman peserta tentang cara mengendalikan cemaran limbah domestik dari hasil evaluasi. Selanjutnya diharapkan warga yang telah paham cara mengendalikan limbah domestik dapat mengembangkannya menjadi produk yang memiliki nilai jual serta menularkannya kepada masyarakat yang lain.

\section{UCAPAN TERIMA KASIH}

Penulis menyampaikan banyak terima kasih kepada Kepala Desa Malangrapat, Kabupaten Bintan atas dukungan dan dedikasinya terhadap kegiatan pengabdian ini.

\section{DAFTAR PUSTAKA}

BPS. (2015). Kepulauan Riau dalam Angka 2014. Badan Pusat Stastistik Kepulauan Riau. Retrieved from https://kepri.bps.go. id/publication/2014/12/23/c9d8d53c23d0 0dd72c85dd4a/kepulauan-riau-dalam-ang ka-2014.html

Elyazar, N., Mahendra, M., \& Wardi, I. (2007). Dampak Aktivitas Masyarakat terhadap Tingkat Pencemaran Air Laut di Pantai Kuta Kabupaten Badung serta Upaya Pelestarian Lingkungan. Ecotrophic: Jurnal Ilmu Lingkungan (Journal of Environmental Science), 2(1), 1-18. Retrieved from https://ojs.unud.ac.id/ index.php/ECOTROPHIC/article/view/2 468

Hindriani, H., Sapei, A., Surihatin, \& Machfud. (2013). Pengendalian Pencemaran Sungai Ciujung berdasarkan Daya Tamping Beban Pencemaran. Jurnal Sumber Daya Air, 9(2), 169-184. Retrieved from https://jurnalsda.pusair-pu.go.id/index.ph p/JSDA/article/view/157

Jovanovic, B. (2017). Ingestion of Microplastics by Fish and Its Potential Consequences from A Physical Perspective. Integrated Environmental Assesment and Management, 13(3), 510-515. https://doi. org/10.1002/ieam.1913

Karuniastuti, N. (2013). Bahaya Plastik terhadap Kesehatan dan Lingkungan. Forum Teknologi, 3(1), 6-14. Retrieved from http://ejurnal.ppsdmmigas.esdm.go.id/sp/ index.php/swarapatra/article/view/43\#: :t 
ext=BAHAYA\%20PLASTIK\%20TERH ADAP\%20KESEHATAN\%20DAN\%20 LINGKUNGAN,-Nurhenu\%20Karunias tuti\&text=Menurut $\% 20$ penelitian $\% 2 \mathrm{C} \% 2$ 0penggunaan\%20plastik\%20yang,pada\% 20tubuh\%20manusia\%20(karsinogenik).

Laapo, A., Fahrudin, A., Bengen, D., \& Damar, A. (2009). Pengaruh Aktivitas Wisata Bahari terhadap Kualitas Perairan Laut di Kawasan Wisata Gugus Pulau Togean. Jurnal Ilmu Kelautan, 14(4), 215-221. Retrieved from https://ejournal.undip.ac. id/index.php/ijms/article/download/1619/ 1382

Muchtar, M. (2012). Distribusi Zat Hara Fosfat, Nitrat dan Silikat di Perairan Kepulauan Natuna. Jurnal Ilmu dan Teknologi Kelautan Tropis, 4(2), 304-317. Retrieved from http://lipi.go.id/publikasi/ distribusi-zat-hara-fosfat-nitrat-dan-silika t-di-perairan-kepulauan-natuna/1657

Rijati, S., Intan, T., \& Subekti, M. (2012). Sosialisasi Daur Ulang Sampah Sebagai Upaya Pengembangan Eko-Budaya di Lingkungan Desa Sayang Jatinangor, Kabupaten Sumedang. Jati Emas, 1(2), 29-34. https://doi.org/10.36339/je.v1i2.4
5

Sawyer, C., McCarty, P., \& Parkin, G. (1994). Chemistry For Environmental Engineering. New York: McGraw-Hill Education

Suriadarma, A. (2011). Dampak Beberapa Parameter Faktor Fisika Kimia terhadap Kualitas Lingkungan Perairan Wilayah Pesisir Karawang-Jawa Barat. Jurnal Riset Geologi dan Pertambangan, 21(2), 21-36. http://dx.doi.org/10.14203/risetge otam2011.v21.43

Tchobanoglous, G., Burton, F., Stensel, H., Metcalf, \& Eddy, I. (2003). Wastewater Engineering: Treatment and Reuse (4th Edition). Boston: McGraw-Hill. Retrieved from https://www.academia. edu/36512973/Wastewater_Engineering_ Treatment_and_Reuse_Fourth_Edition

Yudo, S. (2010). Kondisi Kualitas Air Sungai Ciliwung di Wilayah DKI Jakarta Ditinjau dari Parameter Organik, Amoniak, Fosfat, Deterjen dan Bakteri Coli. Jurnal Air Indonesia, 6(1), 34-42. Retrieved from http://ejurnal.bppt.go.id/index.php/JAI/ar ticle/view/2452 